\title{
Gambaran Komplikasi Oral Pada Pasien yang Menjalani Kemoterapi di Badan Layanan Umum RSUP Prof. Dr. R. D. Kandou Manado
}

\author{
${ }^{1}$ Karel Pandelaki, ${ }^{2}$ Ni Wayan Mariati, ${ }^{3}$ Made Ary Prawira \\ ${ }^{1}$ Fakultas Kedokteran Universitas Sam Ratulangi \\ ${ }^{2}$ Program Studi Kedokteran Gigi Fakultas Kedokteran Universitas Sam Ratulangi \\ ${ }^{3}$ Mahasiswa Program Studi Kedokteran Gigi Fakultas Kedokteran Universitas Sam Ratulangi
}

\begin{abstract}
ABSTRAK
Pasien yang menjalani kemoterapi seringkali mengalami masalah pada rongga mulutnya. Hal ini bisa disebabkan karena agen kemoterapi pada umumnya menyebabkan efek destruktif langsung pada jaringan sekitar rongga mulut dan juga secara tidak langsung dengan menginduksi myelosupresi dan imunosupresi. Komplikasi oral yang banyak dijumpai pada pasien yang menjalani kemoterapi ialah mukositis oral, kandidiasis, xerostomia, gangguan pengecapan dan perdarahan. Tujuan dari penelitian ini yaitu untuk mengetahui gambaran komplikasi oral yang terjadi pada pasien yang menjalani kemoterapi di Badan Layanan Umum RSUP Prof. Dr. R. D. Kandou Manado serta angka kejadian dari komplikasi oral tersebut berdasarkan umur, jenis kelamin, jenis kemoterapi, lama kemoterapi serta jenis kanker yang dialami oleh pasien tersebut. Jenis penelitian ini ialah penelitian deskriptif dengan desain cross sectional study. Pengambilan sampel dilakukan dengan teknik purposive sampling dengan jumlah sampel 64 yang didapat berdasarkan rumus Cochran. Hasil penelitian menunjukkan bahwa xerostomia dan mukositis oral merupakan komplikasi oral yang paling banyak dialami pasien setelah menjalani kemoterapi dengan angka kejadian lebih dari $60 \%$. Sedangkan komplikasi oral lain seperti kandidiasis, gangguan pengecapan dan perdarahan memiliki angka kejadian lebih dari 25\%. Dari hasil penelitian, disarankan kepada para klinisi harus lebih memperhatikan berbagai macam komplikasi oral yang timbul pada pasien yang menjalani kemoterapi. Kerja sama yang baik antara pasien, dokter gigi dan oncologist sangat penting dilakukan untuk meminimalisir angka kejadian komplikasi oral yang ditimbulkan akibat perawatan kemoterapi.
\end{abstract}

Kata kunci: Pasien yang menjalani kemoterapi, komplikasi oral

\begin{abstract}
Patients undergoing chemotherapy often experience problems in oral cavity. This could be happen because the chemotherapy agents cause direct destructive effect on surrounding tissues of the oral cavity, also indirectly by inducing myelosuppression and immunosuppression. Oral complications are often found in patients undergoing chemotherapy is an oral mucositis, candidiasis, xerostomia, taste dysfunction and hemorrhage. The purpose of this research is to describe the oral complications that occur in patients who are undergoing chemotherapy at BLU RSUP Prof Dr. Dr. R. D. Kandou Manado as well as the incidence of oral complications by age, gender, type of chemotherapy, duration of chemotherapy and other types of cancer experienced by these patients. The type of this research is descriptive with cross sectional study. Sampling was done by using purposive sampling with 64 samples were obtained by Cochran formula. The result showed that oral mucositis and xerostomia are the most oral complications experienced by patients after undergoing chemotherapy with an incidence of more than 60\%. While other oral complications such as candidiasis, taste dysfunction and hemorrhage had an incidence of more than 25\%. From the research, it is recommended to clinicians should pay more attention to a variety of oral complications arising in patients undergoing chemotherapy. Good cooperation between the patient, dentist and oncologist is very important to minimize the incidence of oral complications caused by chemotherapy treatment.
\end{abstract}

Keywords: Patients undergoing chemotherapy, oral complications

Koresponden: Made Ary Prawira, Program Studi Kedokteran Gigi Fakultas Kedokteran Universitas Sam Ratulangi. E-mail: madeprawira@gmail.com 


\section{PENDAHULUAN}

Kanker merupakan salah satu penyakit utama penyebab kematian di dunia saat ini. Penyakit kanker merupakan penyakit tidak menular yang berawal dari kerusakan materi genetika atau DNA. Kanker memiliki berbagai karakteristik dengan pertumbuhan sel-sel secara abnormal dan tidak terkendali. Sel-sel kanker ini bisa menyebar kebagian tubuh lainnya. Ketika pertumbuhan dan penyebaran sel-sel abnormal yang tidak terkendali ini dibiarkan serta tidak diobati, maka kematian sangat mungkin terjadi. ${ }^{1,2}$

Kemoterapi merupakan salah satu cara pengobatan kanker dengan menggunakan obat-obatan antikanker yang disebut sitostatika. Kemoterapi merupakan terapi sistemik yang digunakan untuk menghambat pertumbuhan atau membunuh sel-sel kanker. Kemoterapi dapat menjadi bentuk penanganan primer atau tambahan dari terapi radiasi atau pembedahan. $^{3}$

Komplikasi oral yang sering terjadi pada pasien kemoterapi ialah mukositis oral, infeksi oral, xerostomia, perdarahan dan gangguan pengecapan. Frekuensi komplikasi oral yang dapat ditimbulkan bervariasi tergantung dari tipe perawatan yang diberikan. ${ }^{4,5}$

Penelitian yang dilakukan di University of Baghdad, Irak. Dari 125 pasien yang menjalani kemoterapi, seluruhnya mengalami komplikasi oral. Dimana usia 18-24 tahun merupakan usia yang paling banyak mengalami komplikasi oral yaitu $36 \%$ dengan perincian $28 \%$ berjenis kelamin laki-laki dan $8 \%$ berjenis kelamin perempuan. ${ }^{6}$

Penelitian ini juga dilakukan oleh mahasiswa dari Universitas Sumatera Utara yang meneliti komplikasi oral 67 orang pasien kanker yang mendapatkan kemoterapi di RSUP Adam Malik Medan. Hasil penelitian menunjukkan bahwa $94 \%$ dari 67 orang tersebut mengalami minimal 1 lesi komplikasi oral. Komplikasi oral tersebut antara lain 93\% mengalami xerostomia, $63 \%$ mengalami mukositis oral, 24\% mengalami infeksi oral, 19\% mengalami gangguan pengecapan dan $12 \%$ mengalami perdarahan. ${ }^{7}$

Kemoterapi tidak hanya memberikan dampak yang baik, namun memberikan komplikasi yang merugikan bagi pasien. Begitu banyaknya komplikasi yang ditimbulkan akibat agen kemoterapi dengan berbagai prevalensi yang berbeda dari beberapa penelitian yang ada. Berdasarkan latar belakang tersebut maka penulis merasa tertarik pula untuk melakukan penelitian tentang "Gambaran komplikasi oral pada pasien yang menjalani kemoterapi di BLU RSUP Prof. Dr. R. D. Kandou Manado".

\section{BAHAN DAN METODE}

Penelitian ini merupakan penelitian deskriptif dengan menggunakan pendekatan cross sectional dan dilaksanakan di unit kempoterapi dewasa Badan Layanan Umum RSUP Prof. Dr. R. D. Kandou Manado. Sampel dalam penelitian ini ialah pasien yang menjalani kemoterapi di ruang Irina Delima, BLU RSUP Prof. Dr. R. D. Kandou Manado. Pengambilan sampel dilakukan secara unprobability sampling dengan teknik purposive sampling, dimana sampel diambil berdasarkan pertimbangan peneliti sesuaidengan kriteria inklusi dan eksklusi yang telah ditetapkan.

Kriteria inklusi ialah pasien yang menjalani kemoterapi di Ruang Irina Delima, Badan Layanan Umum RSUP Prof. Dr. R. D. Kandou Manado, pasien yang bersedia diperiksa rongga mulutnya, pasien yang dapat membuka mulut dengan 
baik dan pasien yang cukup kooperatif selama melaksanakan prosedur penelitian. Sedangkan kriteria eksklusi ialah pasien yang baru pertama kali datang untuk melakukan kemoterapi, pasien yang tidak bersedia diperiksa rongga mulutnya, pasien yang tidak dapat membuka mulut dengan baik dan pasien yang tidak kooperatif selama prosedur penelitian.

Penelitian ini dilakukan dengan menggunakan data sekunder dan data primer. Pengumpulan data sekunder dilakukan dengan menggunakan catatan rekam medik pasien. Data yang dikumpulkan meliputi data nama, umur, jenis kelamin, jenis kanker, jenis kemoterapi dan lama kemoterapi yang telah dijalani. Pengumpulan data primer dilakukan dengan menggunakan kuesioner dan pemeriksaan secara langsung pada subjek penelitian. Setelah pasien menandatangani informed consent, wawancara dilakukan oleh operator menggunakan kuesioner dengan mengemukakan beberapa pertanyaan untuk memperoleh gambaran tentang kondisi rongga mulut pasien kemoterapi pada saat tersebut. Kemudian dilanjutkan dengan pemeriksaan langsung terhadap subjek penelitian tersebut dengan menggunakan kaca mulut dan spatula kayu untuk mengidentifikasi keadaan mukosa oral. Lesi oral yang terlihat akan diidentifikasi berdasarkan diagnosa klinis. Kemudian data yang diperoleh langsung dari hasil wawancara dan pemeriksan tersebut dicatat dalam lembar yang telah disediakan.

Pengolahan data dilakukan secara manual. Data yang sudah dikumpul kemudian ditabulasikan dan dianalisa. Data tersebut kemudian diolah dengan cara perhitungan persentase setiap komplikasi oral yang terlihat pada pasien yang menjalani kemoterapi. Selanjutnya dilihat jenis kanker, lama kemoterapi dan agen kemoterapi yang memberikan pengaruh yang besar terhadap komplikasi oral tersebut.

\section{HASIL}

Berdasarkan data demografis, jumlah pasien perempuan lebih banyak dibandingkan dengan pasien laki-laki yaitu sebanyak 52 orang $(81 \%)$, sedangkan pasien laki-laki berjumlah 12 orang (19\%). Jumlah pasien kanker yang datang ke BLU RSUP Prof. Dr. R. D. Kandou Manado untuk menjalani kemoterapi paling banyak dijumpai pada kelompok umur 42-47 tahun dengan persentase sebanyak $27 \%$, diikuti oleh pasien pada kelompok umur 54-59 tahun sebanyak $20 \%$ sedangkan jumlah pasien kanker hampir sama terdapat pada kelompok umur 48-53 dan $\geq 60$ yaitu masing-masing sebanyak $17 \%$ dan $16 \%$. Jumlah pasien pada kelompok umur 36-41 tahun sebanyak $11 \%$ dari jumlah sampel penelitian, sedangkan jumlah pasien paling sedikit ialah dari kelompok umur 35 tahun kebawah yaitu hanya $9 \%$.

Berdasarkan jenis kanker, pasien yang paling banyak dijumpai ialah pasien kanker payudara (52\%), diikuti oleh kanker ovarium (11\%), kanker limfoma (9\%) dan kanker serviks (6\%). sedangkan jumlah pasien kemoterapi kanker usus, paru dan lidah masing-masing sebanyak 5\% dari seluruh jumlah sampel. Sedangkan berdasarkan siklus perawatan kemoterapi, paling banyak dijumpai pasien yang telah menjalani 1 siklus perawatan kemoterapi yaitu sebanyak $45 \%$ diikuti dengan pasien yang telah menjalani 3 siklus perawatan kemoterapi sebanyak $17 \%$, sedangkan pasien yang paling sedikit dijumpai ialah pasien yang telah menjalani 4 siklus kemoterapi. Lebih jelas dilihat pada Tabel 1. 
Tabel 1. Data demografis pasien yang menjalani kemoterapi di BLU RSUP Prof. Dr. R. D. Kandou Manado

\begin{tabular}{|c|c|c|c|}
\hline & Variabel & Jumlah (n) & $\%$ \\
\hline \multirow[t]{4}{*}{1.} & Jenis Kelamin & & \\
\hline & a. Laki-laki & 12 & 19 \\
\hline & b. Perempuan & 52 & 81 \\
\hline & Total & 64 & 100 \\
\hline \multirow[t]{8}{*}{2.} & Umur & & \\
\hline & a. $\leq 35$ & 6 & 9 \\
\hline & b. $36-41$ & 7 & 11 \\
\hline & c. $42-47$ & 17 & 27 \\
\hline & d. $48-53$ & 11 & 17 \\
\hline & e. $54-59$ & 13 & 20 \\
\hline & f. $\geq 60$ & 10 & 16 \\
\hline & Total & 64 & 100 \\
\hline \multirow[t]{13}{*}{3.} & Jenis Kanker & & \\
\hline & a. Payudara & 33 & 52 \\
\hline & b. Usus & 3 & 5 \\
\hline & c. Darah & 1 & 2 \\
\hline & d. Nasofaring & 2 & 3 \\
\hline & e. Limfoma & 6 & 9 \\
\hline & f. Paru & 3 & 5 \\
\hline & g. Serviks & 4 & 6 \\
\hline & h. Ovarium & 7 & 11 \\
\hline & i. Pankreas & 1 & 2 \\
\hline & j. Lidah & 3 & 5 \\
\hline & k. Tiroid & 1 & 2 \\
\hline & Total & 64 & 100 \\
\hline \multirow[t]{8}{*}{4.} & Lama & & \\
\hline & Kemoterapi & & \\
\hline & a. Siklus 1 & 29 & 45 \\
\hline & b. Siklus 2 & 8 & 13 \\
\hline & c. Siklus 3 & 11 & 17 \\
\hline & d. Siklus 4 & 7 & 11 \\
\hline & e. Siklus $\geq 5$ & 9 & 14 \\
\hline & Total & 64 & 100 \\
\hline
\end{tabular}

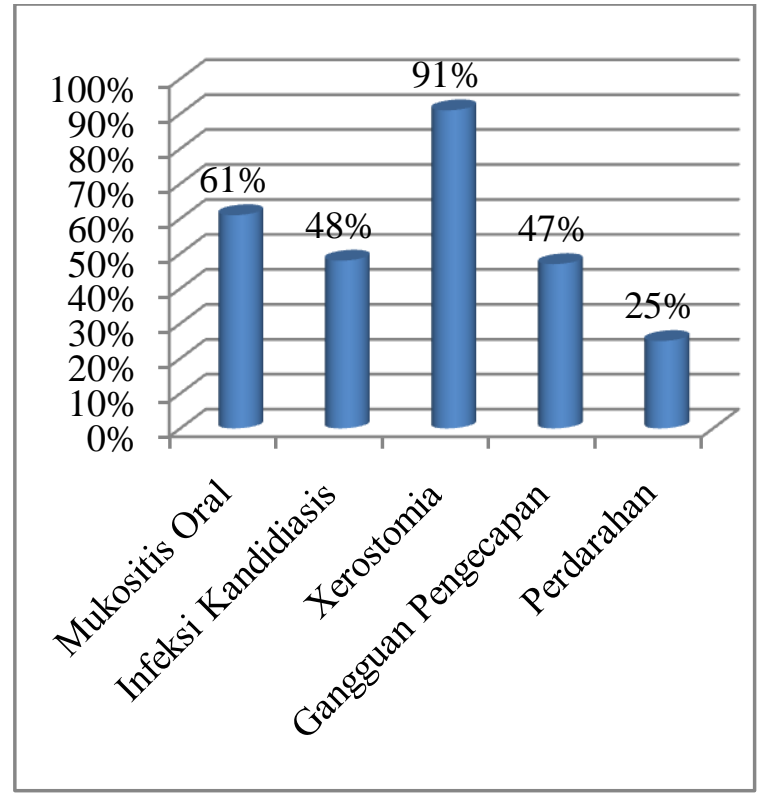

Gambar 1. Angka kejadian komplikasi oral pada pasien yang menjalani kemoterapi di BLU RSUP Prof Dr. R. D. Kandou Manado

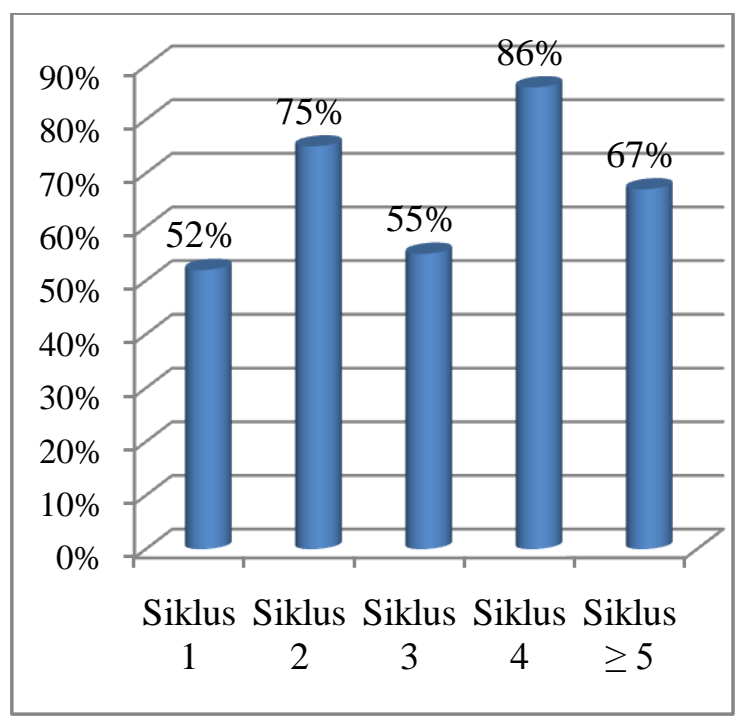

Gambar 2. Angka kejadian mukositis oral berdasarkan siklus perawatan kemoterapi 
Tabel 2. Distribusi komplikasi oral berdasarkan jenis kemoterapi

\begin{tabular}{|c|c|c|c|c|c|}
\hline \multirow{3}{*}{$\begin{array}{c}\text { Jenis } \\
\text { Kemoterapi }\end{array}$} & \multicolumn{5}{|c|}{ Jenis Komplikasi Oral (\%) } \\
\hline & 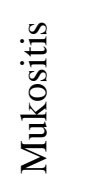 & 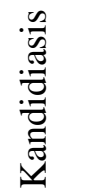 & 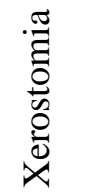 & 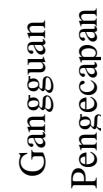 & 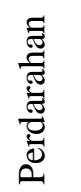 \\
\hline & $\begin{array}{c}\mathrm{n} \\
(\%)\end{array}$ & $\begin{array}{c}\mathrm{n} \\
(\%)\end{array}$ & $\begin{array}{c}\mathrm{n} \\
(\%)\end{array}$ & $\begin{array}{c}\mathrm{n} \\
(\%)\end{array}$ & $\begin{array}{c}\mathrm{n} \\
(\%)\end{array}$ \\
\hline Vinka & 29 & 25 & 42 & 23 & 10 \\
\hline Alkaloid & $74 \%$ & $81 \%$ & $72 \%$ & $77 \%$ & $63 \%$ \\
\hline Alkylating & 21 & 17 & 30 & 16 & 10 \\
\hline Agents & $54 \%$ & $55 \%$ & $52 \%$ & $53 \%$ & $63 \%$ \\
\hline Antibiotics & 19 & 15 & 29 & 16 & 4 \\
\hline Antitumor & $49 \%$ & $48 \%$ & $50 \%$ & $53 \%$ & $25 \%$ \\
\hline Anti & 6 & 6 & 9 & 6 & 1 \\
\hline metabolites & $15 \%$ & $19 \%$ & $16 \%$ & $20 \%$ & $6 \%$ \\
\hline Antibody & 4 & 2 & 5 & 4 & 2 \\
\hline Monoclonal & $10 \%$ & $6 \%$ & $9 \%$ & $13 \%$ & $13 \%$ \\
\hline Biphos- & 1 & 2 & 2 & 1 & 2 \\
\hline phonates & $3 \%$ & $6 \%$ & $3 \%$ & $3 \%$ & $13 \%$ \\
\hline TOTAL & 39 & 31 & 58 & 30 & 16 \\
\hline
\end{tabular}

Tabel 3. Distribusi komplikasi oral berdasarkan umur pasien

\begin{tabular}{|c|c|c|c|c|c|c|}
\hline \multirow[b]{2}{*}{$\begin{array}{c}\text { Umur } \\
\text { (Tahun) }\end{array}$} & \multicolumn{6}{|c|}{ Jenis Komplikasi Oral } \\
\hline & 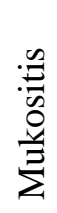 & 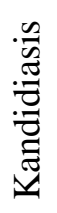 & 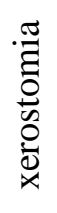 & 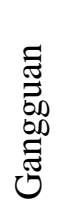 & 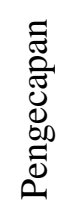 & 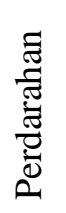 \\
\hline$\leq 35$ & 5 & 2 & 5 & 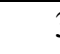 & 3 & 2 \\
\hline $36-41$ & 3 & 2 & 6 & ? & 3 & 2 \\
\hline $42-47$ & 9 & 11 & 17 & & 0 & 3 \\
\hline $48-53$ & 9 & 7 & 10 & ( & 5 & 2 \\
\hline $54-59$ & 8 & 6 & 11 & sina & 5 & 3 \\
\hline$\geq 60$ & 5 & 3 & 9 & ? & 3 & 4 \\
\hline TOTAL & 39 & 31 & 58 & & 0 & 16 \\
\hline
\end{tabular}

Tabel 4. Distribusi komplikasi oral berdasarkan jenis kanker

\begin{tabular}{|c|c|c|c|c|c|}
\hline \multirow{3}{*}{$\begin{array}{c}\text { Jenis } \\
\text { Kanker }\end{array}$} & \multicolumn{5}{|c|}{ Jenis Komplikasi Oral (\%) } \\
\hline & 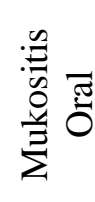 & 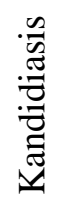 & $\begin{array}{l}\cdot \frac{\pi}{\Xi} \\
\frac{0}{0} \\
0 \\
\stackrel{0}{0} \\
x\end{array}$ & 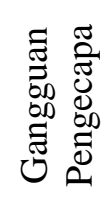 & 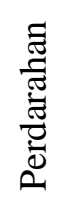 \\
\hline & $\begin{array}{c}\mathrm{n} \\
(\%)\end{array}$ & $\begin{array}{c}\mathrm{n} \\
(\%)\end{array}$ & $\begin{array}{c}\mathrm{n} \\
(\%)\end{array}$ & $\begin{array}{c}\mathrm{n} \\
(\%)\end{array}$ & $\begin{array}{c}\mathrm{n} \\
(\%)\end{array}$ \\
\hline \multirow[t]{2}{*}{ Payudara } & 20 & 16 & 32 & 17 & 7 \\
\hline & $51 \%$ & $52 \%$ & $55 \%$ & $57 \%$ & $44 \%$ \\
\hline \multirow[t]{2}{*}{ Usus } & 2 & - & 1 & - & - \\
\hline & $5 \%$ & & $2 \%$ & & \\
\hline \multirow[t]{2}{*}{ Darah } & 1 & - & 1 & - & - \\
\hline & $3 \%$ & & $2 \%$ & & \\
\hline \multirow{2}{*}{$\begin{array}{l}\text { Naso- } \\
\text { faring }\end{array}$} & 2 & 1 & 2 & 2 & 1 \\
\hline & $5 \%$ & $3 \%$ & $3 \%$ & $7 \%$ & $6 \%$ \\
\hline \multirow{2}{*}{ Limfoma } & 4 & 2 & 4 & 2 & 3 \\
\hline & $10 \%$ & $6 \%$ & $7 \%$ & $7 \%$ & $19 \%$ \\
\hline \multirow[t]{2}{*}{ Paru } & 1 & 1 & 3 & 1 & - \\
\hline & $3 \%$ & $3 \%$ & $5 \%$ & $3 \%$ & \\
\hline \multirow[t]{2}{*}{ Serviks } & 1 & 3 & 4 & 2 & 2 \\
\hline & $3 \%$ & $10 \%$ & $7 \%$ & $7 \%$ & $13 \%$ \\
\hline \multirow[t]{2}{*}{ Ovarium } & 4 & 4 & 7 & 3 & 2 \\
\hline & $10 \%$ & $13 \%$ & $12 \%$ & $10 \%$ & $13 \%$ \\
\hline \multirow[t]{2}{*}{ Pankreas } & 1 & 1 & 1 & 1 & - \\
\hline & $3 \%$ & $3 \%$ & $2 \%$ & $3 \%$ & \\
\hline \multirow[t]{2}{*}{ Lidah } & 2 & 2 & 2 & 2 & 1 \\
\hline & $5 \%$ & $6 \%$ & $3 \%$ & $7 \%$ & $6 \%$ \\
\hline \multirow[t]{2}{*}{ Tiroid } & 1 & 1 & 1 & - & - \\
\hline & $3 \%$ & $3 \%$ & $2 \%$ & & \\
\hline TOTAL & 39 & 31 & 58 & 30 & 16 \\
\hline
\end{tabular}

\section{PEMBAHASAN}

Berdasarkan hasil penelitian di BLU RSUP Prof. Dr. R. D. Kandou Manado, angka kejadian komplikasi oral pada pasien yang menjalani kemoterapi antara lain $91 \%$ pasien mengalami xerostomia, $61 \%$ mengalami mukositis oral, $48 \%$ mengalami kandidiasis, $47 \%$ mengalami gangguan pengecapan dan $25 \%$ mengalami perdarahan. Jika dibandingkan dengan hasil penelitian sebelumnya yaitu penelitian oleh mahasiswa dari Universitas Sumatera Utara di RSUP Adam Malik Medan, angka kejadian komplikasi oral pasien yang mendapatkan kemoterapi 
antara lain 93\% dari seluruh pasien tersebut mengalami xerostomia, $63 \%$ mengalami mukositis oral, $24 \%$ mengalami kandidiasis oral, $19 \%$ mengalami gangguan pengecapan dan $12 \%$ mengalami perdarahan. ${ }^{7}$

Pada hasil penelitian di RSUP Adam Malik Medan, angka kejadian xerostomia menjadi komplikasi oral terbanyak yang dialami oleh pasien yang menjalani kemoterapi yaitu sebanyak 93\%. ${ }^{7}$ Hasil tersebut hampir serupa dimana angka kejadian xerostomia pada pasien kemoterapi di BLU RSUP Prof. Dr. R. D. Kandou Manado sebanyak 91\%. Kemoterapi memberikan dampak yang nyata pada mukosa oral dimana terjadinya gangguan pada sekresi saliva yang pada akhirnya menyebabkan keadaan mukosa mulut kering sehingga meningkatkan resiko infeksi dan gangguan dalam berbicara, mengunyah dan menelan. ${ }^{1,8}$

Angka kejadian mukositis oral yang didapat berdasarkan hasil penelitian ini yaitu sebanyak 61\%. Hasil ini hampir serupa dibandingkan dengan hasil penelitian sebelumnya dimana angka kejadian komplikasi mukositis oral yang terjadi pada pasien kanker akibat kemoterapi di RSUP Adam Malik Medan sebanyak $63 \% .^{7}$ Mukositis oral adalah peradangan pada lapisan mukosa oral yang dapat menyebabkan ulserasi dan merupakan komplikasi oral yang paling umum terkait dengan penggunaan agen kemoterapi. ${ }^{1,9}$

Angka kejadian komplikasi kandidiasis pada pasien yang menjalani kemoterapi berdasarkan hasil penelitian ini yaitu sebanyak $48 \%$. Hasil ini jauh lebih tinggi dibandingkan dengan hasil penelitian sebelumnya dimana kandidiasis hanya terjadi pada $24 \%$ dari seluruh pasien kanker yang menjalani kemoterapi. ${ }^{7} \mathrm{Hal}$ ini diduga karna lebih beragamnya regimen kemoterapi yang digunakan oleh pasien kemoterapi di BLU RSUP Prof. Dr. R. D. Kandou Manado seiring dengan makin berkembangnya jenis obat-obatan kanker dan ditambah dengan kombinasi berbagai macam regimen kemoterapi yang digunakan secara bersamaan.

Gangguan pengecapan akibat kemoterapi pada penelitian ini sebanyak $47 \%$ dari 64 orang pasien. Gangguan pengecapan pada pasien kemoterapi memang sangat sering terjadi. ${ }^{10}$ Makanan yang dimakan dapat terasa seolah-olah tawar. Perubahan ini terjadi karna adanya kerusakan pada taste bud lidah, kekeringan mulut, infeksi dan gigi berlubang. Biasanya indra pengecapan ini kembali berfungsi baik setelah 6-8 minggu pasca pengobatan kanker selesai. ${ }^{11}$

Angka kejadian perdarahan pada penelitian ini ialah sebanyak 25\%. Agen kemoterapi secara sekunder menyebabkan trombositopenia yang merupakan penyebab umum perdarahan intraoral. Perdarahan dapat dilihat secara klinis sebagai perdarahan gingiva atau perdarahan submukosa (petechia dan ecchymosis) dengan pembentukan hematoma. ${ }^{1}$

Pasien yang datang ke BLU RSUP Prof. Dr. R. D. Kandou Manado untuk melakukan kemoterapi paling banyak ialah berjenis kelamin perempuan. Hal ini disebabkan karena insidensi kanker payudara di BLU RSUP Prof. Dr. R. D. Kandou Manado memang tinggi sehingga pasien yang melakukan kemoterapi paling banyak ialah pasien perempuan yang menderita kanker payudara.

Jenis kanker yang paling banyak dialami oleh pasien yang menjalani kemoterapi di BLU RSUP Prof. Dr. R. D. Kandou ialah kanker payudara yaitu 
sebanyak 52\%, diikuti dengan kanker ovarium, limfoma dan serviks. Hasil penelitian sebelumnya di RSUP Adam Malik Medan juga menunjukkan bahwa kanker payudara juga merupakan merupakan jenis kanker yang paling banyak dialami oleh pasien yang menjalani kemoterapi.

Berdasarkan umur, pasien yang mengalami komplikasi oral paling tinggi ialah pada kelompok umur 42-47 tahun. Pada 39 pasien yang mengalami mukositis oral, paling banyak dijumpai pasien pada kelompok umur 42-47 dan 48-53 tahun sebanyak 9 orang. Kandidiasis, xerostomia dan gangguan pengecapan juga paling banyak dijumpai pada pasien kelompok umur 42-47 tahun. Jumlah pasien yang mengalami perdarahan hampir sama pada setiap kelompok umur, namun paling banyak terdapat pada kelompok umur $\geq 60$ yaitu sebanyak 4 orang. Dari semua kelompok umur, kelompok umur $\leq 35$ dan 36-41 tahun yang paling sedikit mengalami komplikasi oral setelah menjalani kemoterapi.

Pada penelitian ini, angka kejadian mukositis oral paling banyak terdapat pada pasien yang telah menjalani kemoterapi pada siklus ke 4 yaitu sebanyak $86 \%$. Sedangkan angka kejadian mukositis oral yang paling sedikit terdapat pada pasien yang telah menjalani kemoterapi siklus ke 1 yaitu hanya $52 \%$. Pada hasil penelitian ini, dapat dilihat bahwa pasien yang menjalani kemoterapi sampai pada siklus ke 4 mengalami komplikasi mukositis oral yang paling banyak dibandingkan dengan siklus lainnya.

Pada penelitian ini, jenis kemoterapi yang paling banyak menimbulkan komplikasi oral ialah dari jenis vinka alkaloid seperti paxus dan brexel. Vinka alkaloid merupakan agen anti tumor yang bertindak secara khusus dengan menghambat pembelahan sel selama mitosis. ${ }^{12}$ Selain itu, jenis kemoterapi alkylating agents juga memberi dampak komplikasi oral yang besar. Alkylating agents bekerja menghambat sintesis DNA dengan menukar gugus alkali sehingga membentuk ikatan silang DNA dan bekerja pada siklus sel fase nonspesifik artinya sel-sel tubuh yang sehat pun dapat dipengaruhi oleh obat ini. ${ }^{1}$

\section{SIMPULAN}

1. Jenis kemoterapi yang paling banyak menimbulkan komplikasi oral yaitu golongan vinka alkaloid (74\%), disusul oleh golongan alkylating agents (49\%).

2. Komplikasi oral paling banyak dijumpai pada pasien yang telah menjalani 4 siklus kemoterapi dibanding siklus-siklus lainnya yaitu dengan prevalensi $86 \%$, sedangkan yang paling sedikit yaitu pasien yang telah menjalani 1 siklus kemoterapi dengan angka kejadian sebanyak 52\%.

3. Angka kejadian komplikasi oral paling banyak dijumpai pada pasien dengan jenis kanker payudara (51\%), diikuti oleh jenis kanker ovarium dan limfoma masing-masing $10 \%$.

4. Komplikasi xerostomia dan mukositis oral merupakan komplikasi yang paling banyak dialami oleh pasien kemoterapi dimana angka kejadiannya mencapai lebih dari $60 \%$.

5. Pasien kemoterapi yang paling banyak dijumpai yaitu pasien perempuan, sedangkan kelompok umur yang paling banyak dijumpai yaitu dari kelompok umur 42-47 tahun (27\%). 


\section{SARAN}

1. Disarankan kepada masyarakat terutama pada pasien yang menjalani kemoterapi agar lebih lagi dalam menjaga kebersihan gigi dan mulut untuk meminimalisir komplikasi oral akibat kemoterapi.

2. Disarankan kepada institusi pendidikan untuk lebih banyak menyediakan referensi tentang manifestasi oral yang bisa timbul akibat suatu perawatan penyakit misalnya akibat perawatan kemoterapi ini. Karna hal ini dapat menambah pengetahuan serta dapat menjadi sumber referensi mahasiswa Kedokteran Gigi mengenai komplikasi oral pada pasien akibat suatu perawatan penyakit tertentu.

3. Disarankan pada para klinisi agar lebih memperhatikan berbagai macam komplikasi oral yang timbul pada pasien yang menjalani kemoterapi. Kerjasama dari pihak pasien, dokter gigi dan oncologist sangat diperlukan untuk meminimalisir angka kejadian komplikasi oral yang timbul akibat perawatan kemoterapi.

4. Diharapkan pada peneliti lain untuk melakukan penelitian lebih lanjut lebih dalam, terutama dalam melakukan diagnosa yang tidak hanya berdasarkan diagnosa klinis namun juga dilakukan dengan diagnosa penunjang seperti hasil pemeriksaan laboratorium.

\section{DAFTAR PUSTAKA}

1. Toscano N, Holtzclaw D, Hargitai IA, Shumaker N, Richardson H, Naylor G, Marx R. Oral Impications of Cancer Chemotherapy. JIACD Continuing Education 2009;1(5):1-19

2. American Cancer Society. The History of Cancer. New York: American Cancer Society; 2012. p.1-6
3. Susan G. Chemotherapy and Side Effects. Saint Louis : American Cancer Society; 2009.

4. Cancer Care Nova Scotia. Best Practice Guidelines for The Management of Oral Complications from Cancer Therapy. [online] 2007 [cited 2013 Apr 25]; [104 screens]. Available from: URL: http://www.cancercare.ns.ca/sitec/media/cancercare/Oral_Care_CV_FINA L.pdf

5. Watters AL, Epstein JB, Agulnik M. Oral Complications of Targeted Cancer Therapies. [serial online] 2011 [cited 2013 May 3]; [8 screens].

6. Wafaa, Dr; Rajaa, Dr; Sajid, Mr. Oral Complications in Adult Patients Under Chemoteraphy Treatment. Baghdad : University of Baghdad: 2010.

7. Kamarudin NAA. Prevalensi Komplikasi Oral Akibat Kemoterapi pada Pasien Kanker di RSUP Adam Malik Medan. Medan: Universitas Sumatera Utara; 2009. Skripsi.

8. Oncology Team. Oral Complications of Cancer Treatment. [online]. 2009 [cited 2013 Apr 24]; [6 screens]. Available from: URL:

http://www.nidcr.nih.gov/NR/rdonlyres/01 5DE57E-92CC-427C-A084022245B5D4F5/0/OncologyTeamCanDo. pdf

9. Peterson DE, DMD, PhD. New Strategies for Management of Oral Mucositis in Cancer Patients. [serial online] Feb 2006 [cited 2013 Jun 22]; 4(2):[14 screens]. Available from: URL: http://www.oncologypractice.com/jso/jour nal/articles/0402s109.pdf

10. Zabernigg A, Gamper EA, Giesinger J, Rumpold G, Kemmler G, Gattringer K et al. Taste Alterations in Cancer Patients Receiving Chemotherapy. Austria: Innsbruck Medical University; p. 2-14

11. Boltong AG. Does Chemoteraphy Influence Basic Taste Perception and Hedonic Experience? Adelaide: University of Adelaide; 2010.

12. Martinez CC, Casado P, Rodriguez R, Zuazua P, Garcia PJM, Lazo PS et al. Effect of Vinca Alkaloids on ER $\alpha$ levels and Estradiol-induced responses in MCF-7 cells. Oviedo: Breast Cancer Research and Treatment; p. 81-9 